KKLP STIE STKIP YAPTI JENEPONTODESA PAITANA

KEC.TURATEA KAB.JENEPONTO ANGKATAN XXII

(PEMBUATAN DAN PERBAIKAN TIANG PKK SERTA 10

PROGRAM PKK)

NAMA:ABD IRWANSYAH

NIRM:19183770410360

\title{
EMAIL: abdirwansyah077@gmail.com
}

\section{BENTUK KEGIATAN}

Melaksanakan kegiatan pembuatan dan perbaikan tiang pkk,seperti 10 program pkk yang di buat oleh para mahasiswa(i)dan juga perbaikan tiang hatinya.didesa paitana kecematan turatea kabupaten jeneponto

\section{LOKASI}

- Rumah kepala dusun rannayya

- Rumah jabatan dan kantor camat turatea

3.HARI/TANGGAL DAN WAKTU

RABU

PUKUL:04.00

4.PESERTA YANG DI LIBATKAN

- MAHASISWA KKLP STIE/STKIP YAPTI JENEPONTO

- APARATUR PEMERINTAHAN CAMAT TURATEA

\section{ALASAN DI ADAKANNYA}

Adanya tim penilaian dan PKK kabupaten di kantor camat turatea KAB. Jeneponto

6. TUJUAN DAN MANFAAT

- Untuk menjalankan program PKK KEC. Turatea desa paitana 
- Meningkatkan aktivitas dan kerja program PKK KEC. Turatea KAB. Jeneponto

\section{DESKRIPSI KEGIATAN}

Dalam hal kegiatan yang di lakukan oleh mahasiswa(i) para mahasiswa terlebih dahulu berkordinasi dengan camat turatea sebelum melakukan kegiatan program kerja(pkk),setelah itu mahasiswa mengambil bahan dan perlengkapan seperti papan dan balok untuk dilakukannya program pembuatan tiang pkk dan programnya di rumah kepala dusun rannayya.sementara mahasiswa lainya membantu pengecetan beberapa kegiatan program kklp(pkk desa paitana kec.turatea) 